\begin{tabular}{|l|l|l|l|l|}
\hline ACTA CARSOLOGICA & $32 / 1$ & 4 & $39-56$ & LJUBLJANA 2003 \\
\hline
\end{tabular}

COBISS: 1.01

\title{
PATTERN OF KARST LANDSCAPE OF THE CRACOW UPLAND (SOUTH POLAND)
}

\author{
ZASNOVA KRAŠKE POKRAJINE KRAKOVSKEGA VIŠAVJA \\ (JUŽNA POLJSKA)
}

STEFAN WITOLD ALEXANDROWICZ ${ }^{1} \&$ ZOFIA ALEXANDROWICZ ${ }^{2}$

\footnotetext{
${ }^{1}$ Polish Academy of Arts and Sciences, Sławkowska 17, 31-016 KRAKÓW, POLAND e-mail: office@pau.krakow.pl

${ }^{2}$ Institute of Nature Conservation, Polish Academy of Sciences, Mickiewicza 33, 31-120 KRAKÓW, POLAND, e-mail: alexandrowicz@iop.krakow.pl
} 


\section{Stefan Witold Alexandrowicz \& Zofia Alexandrowicz: Pattern of karst landscape of the Cracow Upland (South Poland)}

The relief of the Polish Jura Chain developed since Paleogene under climatic conditions changing considerably. Their main components are a peneplain crowned by numerous monadnocks, generated as hard-rocks on Upper Jurassic massive limestones (bioherms, carbonate buildups) surrounded by less resistant platy and bedded limestones of the same age. After the Miocene tectonic phase and following karstification deep valleys dissected the top surface of the plateau and cave levels connected with rocky terraces had been formed. During the Pleistocene the periglacial climate accelerated the congelifraction and relaxation of monadnocks. The modification of landforms and the environment in last ten thousand years, indicated by assemblages of molluscs was controlled by both climatic and anthopogenic factors. The geo- and biodiversity closely related to one another are still under the nature protection.

Key words: karst relief, monadnocks, malacofauna, environment, nature protection, Cracow Upland, Poland.

Stefan Witold Alexandrowicz \& Zofia Alexandrowicz: Zasnova kraške pokrajine Krakovskega višavja (južna Poljska)

Površje Poljske Jure se že od paleogena razvija v zelo spremenljivih klimatskih pogojih. Gre za ravnik (peneplen), posejan s številnimi monadnoki iz gorjnejurskega masivnega apnenca, ki jih obdaja manj odporni, tanko plastoviti apnenec iste starosti. Miocenski tektonski fazi je sledilo zakrasevanje, v planoto so se zarezale globoke doline, nastalo pa je tudi več jamskih nivojev. V pleistocenu je periglacialna klima pospešila kongelifrakcijo in sprostitev monadnokov. Združbe mehkužcev kažejo na antropogeno in klimatsko pogojeno spreminjanje površja in okolja $v$ zadnjih deset tisočih letih. Izredna geološka in biološka pestrost področja sta zaščitena.

Ključne besede: kraški relief, monadnoki, malakofauna, okolje, zaščita narave, Krakovsko višavje, Poljska. 


\section{INTRODUCTION}

The Polish Jura Chain spreads out between Cracow, Częstochowa and Wielun as the most typical karstland of Poland. It is the upland extending across the Silesian-Cracow Monocline build of geological formations representing the time span Middle Devonian - Upper Cretaceous and inclined gradually to NE. The differentiated relief of this area corresponds both to various resistance of the bedrock and their geological development. The southern segment of the region the Cracow Upland, encloses two different types of the landscape. Ojców Plateau covers their main part, reaching the mean altitude of $450-480 \mathrm{~m}$ a.s.l. with the culminating point $512 \mathrm{~m}$ a.s.l. (monadnock "Grodzisko" in Jerzmanowice). It passes southward to the other part of the upland characterised by the structural relief reflecting numerous faults, horsts and grabens. It is just the northern marginal zone of the Carpathian Foredeep.

The described area has been investigated since more than hundred years by Zaręczny (1894), Dżułyński (1952), Walczak (1956), Pokorny (1963), Dżułyński et al. (1966) and other authors dealing with both geological history and morphogenesis. The main purpose of our investigations presented now was to verify opinions about the origin and transformation of rocky landforms spread over the Ojców Plateau, described as mogotes, monadnocks, limestone tors and so on. Malacological analysis was adopted and used to indicate changes of the environment since the termination of Pleistocene. The results will be used to point out the most important objects and areas proposed to the European framework of geosites and to motivate the concept of Jurassic Geopark of the Cracow-Częstochowa Upland.

The present study is a contribution to two scientific projects. One of them has been carried out in co-operation between the Polish Academy of Arts and Sciences (PAU) and Slovenian Academy of Sciences and Arts (SAZU) (Slovenian-Polish joint project) while the other is supported by the Polish State Committee for Scientific Research (KBN - 3 PO4G 092 23).

\section{RELIEF OF THE OJCÓW PLATEAU}

The elevated part of the Cracow Upland extends across rocks of various ages, but mainly over the Upper Jurassic (Oxfordian) limestones. They crop out along rocky valleys and gorges, on slopes and vertical scars of rocky hills and also in a few abandoned quarries. The top plain of the

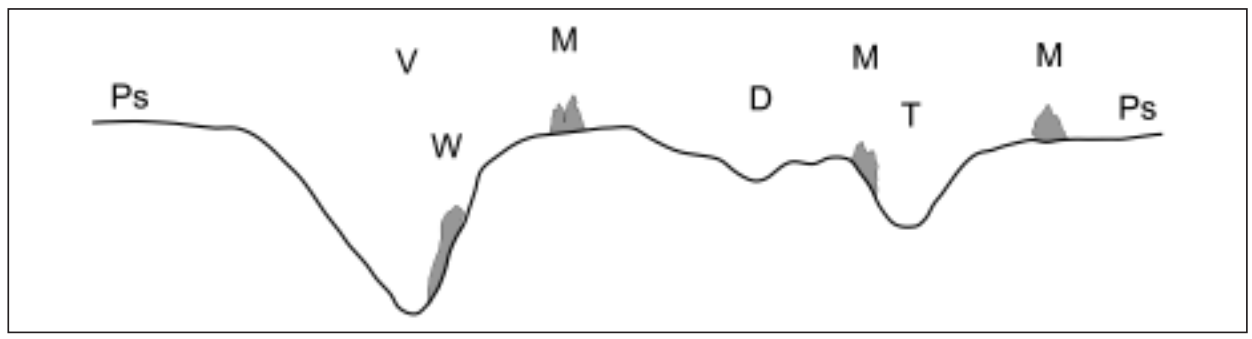

Fig. 1: Sketch of main elements of the karst landscape. Ps - planation surface, $V$ - deep valleys, $T$ - temporary drained valleys, $D$ - denudation valleys (dellen), $W$ - towers and rocky slopes of valleys, $M$ - monadnocks. 


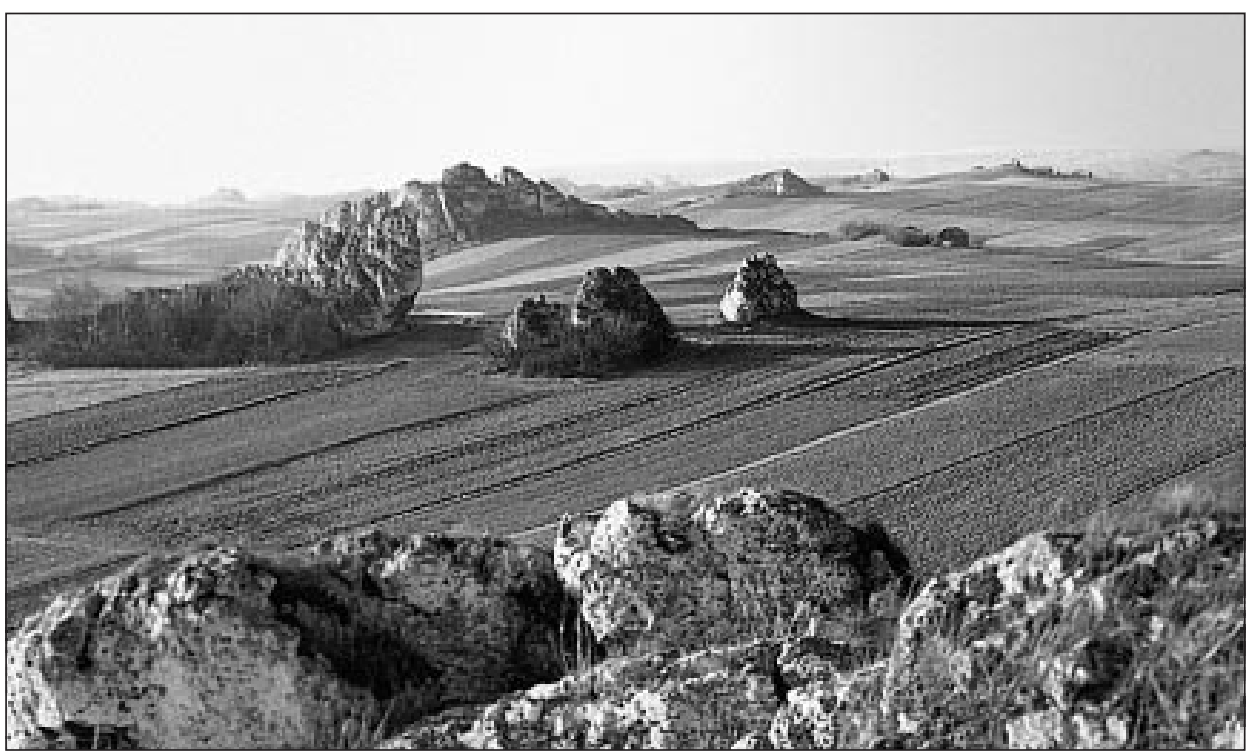

Fig. 2: Top plain of the Ojców Plateau crowned with monadnocks, the vicinity of Jerzmanowice (J. Matecki, 1950).

plateau is nearly flat with traces of dry denudation valleys, numerous rolling hills and limestone monadnocks (Fig. 1). Monolithic rocks raising over the plain dominates in the landscape as their most characteristic components (Fig. 2).

According to Klimaszewski (1958), Pokorny (1963) and other authors, the planation or denudation surface of the Ojców Plateau had been developed as a peneplain during a long time under the impact of warm and humid climate, particularly favourable to the activity of denudation and karst processes. Numerous monadnocks determined as mogotes were formed subsequently.

Only covering sediments may indicate the age of this peneplain. They were deposited by slopewash and sheetflood or occur as carpets of residual clays accumulated in flat karst depressions, in caves and enlarged fissures. The age of these sediments was estimated to Paleogene or Paleogene - Lower Miocene (Klimaszewski 1958, Pokorny 1963, Gradziński 1977, Felisiak 1992), unfortunately it has been not confirmed by paleontological evidence till now. In particular localities the sediments in question rest directly on karstified surface of Upper Jurassic limestones and are covered with Quaternary sand or loam, therefore their age interval was very large. Only in one place (Rudawa, about $20 \mathrm{~km}$ westward of Cracow) the stratigraphic sequence of well-dated formations including the described deposits was found (Alexandrowicz 1969). The sequence from the bottom upward is as follow:

- Upper Jurassic bedded limestones with brachiopods (Lacunosella cracoviensis),

- sandy limestones with fragments of Inoceramus (Lower Turonian),

- grey marls with numerous Foraminifera typical of the Santonian - Lower Campanian,

- green clays covered with white sand resembling karst deposits from the upland,

- grey sandy and marly clays abounding in fossils typical of Lower Badenian. 
Clay and sand which separate Upper Cretaceous and Middle Miocene deposits in this sequence are therefore really of Paleogene - Lower Miocene age. They reach $20 \mathrm{~m}$ of the thickness and represent the new defined Rudawa Formation. In the mentioned type profile these sediments occur not as the filling of a karst hole or a cave within the Upper Jurassic limestones, but they rest on the old surface of Upper Cretaceous marls decalcified at the top (Alexandrowicz 1969).

Deposits covering the karstified limestone surface, are called locally "Moulding Sands" (Krysowska-Iwaszkiewicz 1974, Gradziński 1977). They crop out and are temporary quarried in several localities, mainly in the Częstochowa Upland. It is the same geological formation as residual clays filling flat depressions on the Ojców Plateau (Klimaszewski 1958, Pokorny 1963). Quite similar but distinctly differentiated sediments fill more or less enlarged fissures, karst channels and caves within Upper Jurassic limestones (Felisiak 1992). They occur in numerous outcrops, rocky walls and abandoned quarries in the whole upland (Alexandrowicz 1960, Gradziński 1962). Silicified shells of Santonian-Campanian foraminifers and numerous sponge spicules deriving mainly from Upper Cretaceous marls but also from Upper Jurassic limestones, were found both in these sediments and in mentioned Paleogene - Lower Miocene clay or sand from the geological stratotype profile in Rudawa.

Mineral composition of clays has been used to specify the age of mentioned deposits (Krysowska-Iwaszkiewicz 1974). The considerable content of kaolinite typical of sediments found

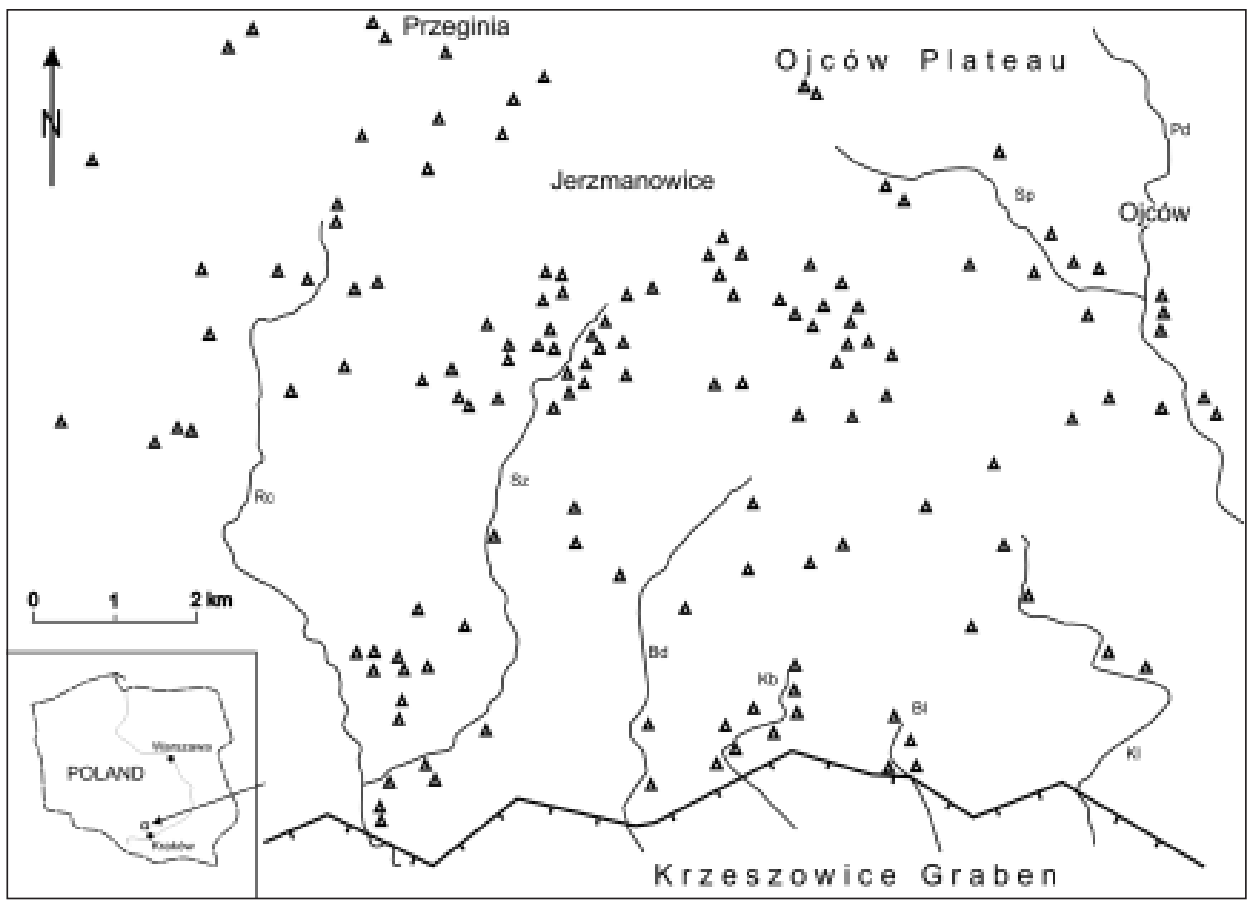

Fig. 3: Distribution of monadnocks (triangles) within the Ojców Plateau. Rc - Ractawka Valley, Sz - Szklarka Valley, Bd - Będkowska Valley, Kb - Kobylanka Valley, Bl - Bolechowicka Valley, Kl - Kluczwoda Valley, Sp - Saspówka Valley, Pd - Prąnik Valley. 
in karst depressions on the top surface of the plateau is connected with the warm climate of the Eocene. The domination of smectites noted in the Rudawa Formation and in clays filling fissures and karst forms in the southern part of the Cracow Upland suggests the more temperate climate of the Oligocene - Lower Miocene (Felisiak 1992).

Valleys and gorges dissecting the Ojców Plateau are usually narrow and deep up to scores or even hundred meters. Steep slopes and rocky walls border the lower and middle courses of these valleys, while in upper course they pass to temporary drained, dry valleys and finally into denudation valleys (dellen), gradually vanishing within the top surface of the plateau. Valleys of streams and rivers run parallel to the main directions of joint measured on rocky walls. Rivers crossing the most part of the Ojców Plateau are tributaries of the Rudawa River, which flows along the Krzeszowice Graben. Only the Prądnik River and the Dłubnia River flow directly to the Vistula River.

Three rocky terraces and corresponding cave levels are important features of the described valleys (Dżułyński et al. 1966, Gradziński 1962, 1977). They had been generated during the Pliocene, after tectonic phase creating the system of faults connected with the development of the Carpathian Foredeep (Dżułyński et al. 1966, Bogacz 1967). In the Late Pleistocene and Holocene the discontinuous loess terrace and travertine terraces formed along the bottom of particular valleys. Together with the low mud-terrace these are the youngest elements of their morphology.

Numerous rocky forms of different shape and size occur on the summit of the Ojców Plateau (Fig. 3). They had been formed at the same time as the planation level and were later modified by karst processes in the warm climate of the Pliocene and in the moderate climate of Pleistocene interglacials as well as in periglacial conditions during multiple Quaternary glaciations.

\section{MONADNOCKS}

Rocky hills, domes, towers, cones, ridges, walls, pinnacles and spires raising up to $30 \mathrm{~m}$ above the top level of the Polish Jura Chain crown their summit. They were described as mogotes or monadnocks and are most spectacular components of the karst landscape (Klimaszewski 1958, Pokorny 1963). The lithology and structure of the bedrock, particularly the differentiation of Jurassic limestones and system of joint are main agents controlling the origin and transformation of these forms.

Three main types of Oxfordian limestones occur in the Cracow Upland as lithofacies replacing each other: platy limestones, bedded limestones with cherts and massive limestones (Dżułyński 1952, Alexandrowicz 1960, Matyszkiewicz 1997). The last mentioned are distinctly diversified. In the Lower Oxfordian these are mostly small bioherms developed within platy and marly limestones (Fig. 4 - Ml-Bh) while in the Middle and Upper Oxfordian - more or less thick carbonate cyanobacterial-sponge buildups passing laterally to bedded limestones (Fig. 4 - Ml-Cb).

According to the model of architecture of the Upper Jurassic sedimentary basin in South Poland massive limestones formed submarine ridges and elevations surrounded by depressions, where the deposition of bedded limestones with cherts took place (Matyszkiewicz 1997 - Fig. 18). This model is the key to understand the distribution and the origin of monadnocks on the top surface of the upland as well as rocky walls and limestone towers in valleys of streams and rivers. Massive limestones as more resistant to weathering, karstification and denudation were being 


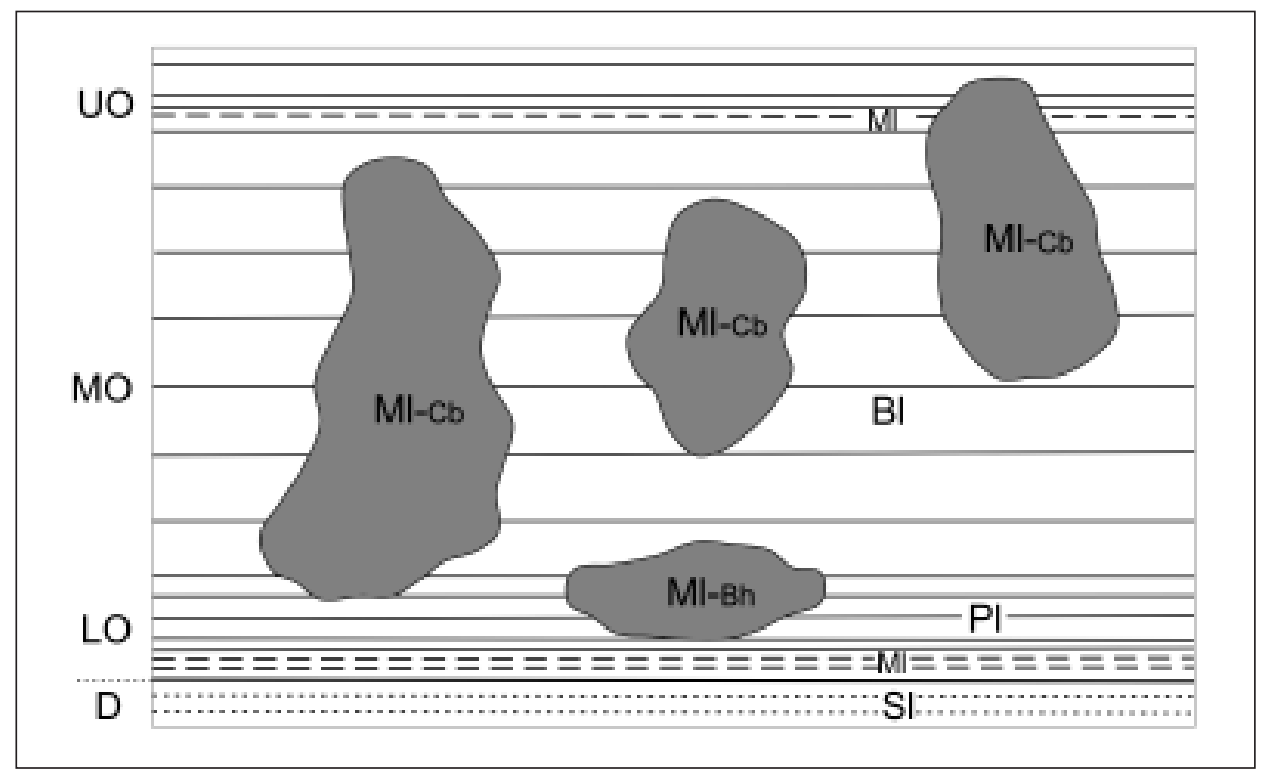

Fig. 4: Types of Jurassic limestones in the Cracow Upland. D - Dogger, LO - Lower Oxfordian, MO - Middle Oxfordian, UO - Upper Oxfordian, Sl - sandy limestones, Ms - marls, Pl - platy limestones, $\mathrm{Bl}$ - bedded limestones, $\mathrm{Ml}$-Bh - massive limestones - small bioherms, $\mathrm{Ml}$-Cb-massive limestones - carbonate buildups.

gradually separated by the selective denudation from less resistant platy and bedded limestones surrounding them. Therefore all described monadnocks should be interpreted as hard-rocks connected exclusively with carbonate buildups. Such interpretation is in accordance with opinions of former authors (Klimaszewski 1958, Pokorny 1963, Dżułyński et al. 1966).

Carbonate buildups are distributed in different parts of the profile of Upper Jurassic deposits. The considerable part of them is connected with the middle segment of the sequence (Middle Oxfordian), therefore monadnocks are particularly numerous in the central part of the plateau, around villages Jerzmanowice and Przeginia. Only several of them spread along the south-western margin of the Ojców Plateau as more old buildups, sitting within the lower segment of the sequence, close to the bottom of Upper Jurassic limestones and marls (Lower - Middle Oxfordian). The youngest massive limestones occur within bedded limestones with cherts, intercalated with a few thin layers of fossiliferous marls containing a rich assemblage of foraminifers (Fig. 4). It indicates the biostratigraphic zone Idoceras planula of Upper Oxfordian (Barwicz-Piskorz 2001). Monadnocks related to this zone occur in the Dhubnia river valley near Imbramowice, at the north-eastern margin of the plateau.

The size of monadnocks depends in significant degree on the size and shape of carbonate buildups. Forms connected with large and deep-rooted massive limestones are relatively big and stable. On the other hand flat-rooted buildups give small rocky forms suitable to gravitational deformations. Big monadnocks cover the surface exceeding 25 ares $\left(2500 \mathrm{~m}^{2}\right)$ and reaches up to 
Fig. 5: Size of monadnocks on top surface of the Ojców Plateau.

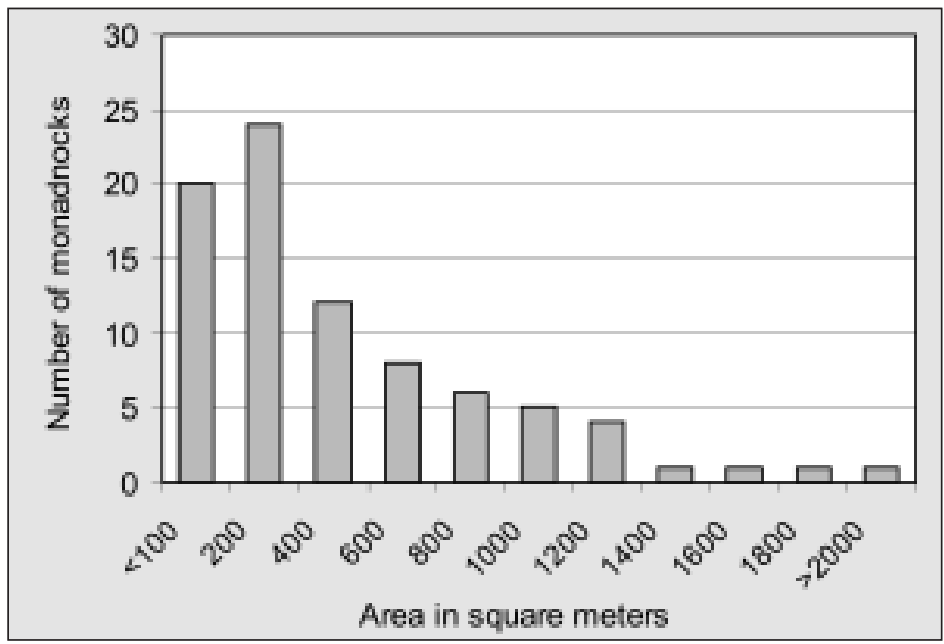

20 - 30 m high, but the most of them do not exceed 7 - 10 ares and are much lower (Fig. 5). In the Częstochowa Upland several these forms are few times greater.

Monadnocks of different shape and size are usually bordered parallel to main directions of joint. Single monoliths resemble rocky cones, towers and pinnacles with steep or vertical walls distinctly karstified. Their vertical outline is frequently modified by traces of horizontal or gently inclined bedding somewhat enlarged by solution. Small holes and caverns concentrate locally along them. Fragments of fossils protruding from the surface appear as less dissoluble in relation to surrounding rock.

Large forms are usually divided into parts along more or less enlarged fissures where solution takes place along vertical lines of jointing. Particular parts of them as more resistant monoliths are relatively high in relation to other ones distinctly lowered, aided to weathering due to the increased joint (Figs. 6, 7). The diversified microrelief reflects the advanced karstification while fresh and smooth scars indicate that slope failure and breakdown of blocks and rock fragments still occurs. The detachment of blocks from the free faces of a rocky hills or monadnocks has produced pinnacles in some places as well as huge blocks fallen down and imitating small rocky forms rooted at the base. This process gives usually a lot of rock detritus and scree accumulated as cones at the foot of rocky walls. The rate of scree formation is much slower today than it must have been during the glacial period, when the congelifration of rocky cliffs was very intensive.

In many rocky hills and large monadnocks effect of gravitational displacement are clearly visible. Particular monoliths divided by enlarged fissures subside unequally, draw aside, incline or even fall down. Fissures became more and more enlarged, V-shaped and sometimes closed from the top by big lose, detached limestone blocks. Small rock shelters originate in that way. Wide fissures bordered by vertical walls form corridors or even orthogonal systems of corridors resembling small rocky labyrinths.

Transformation of monadnocks by this type of mass movements was permanent during the long time. It has been accelerated most of all in the Pleistocene under the influence of periglacial climate, mainly permafrost. At that time it was the dominant destructive factor leading to congelifration and disintegration of rocky cliffs. 


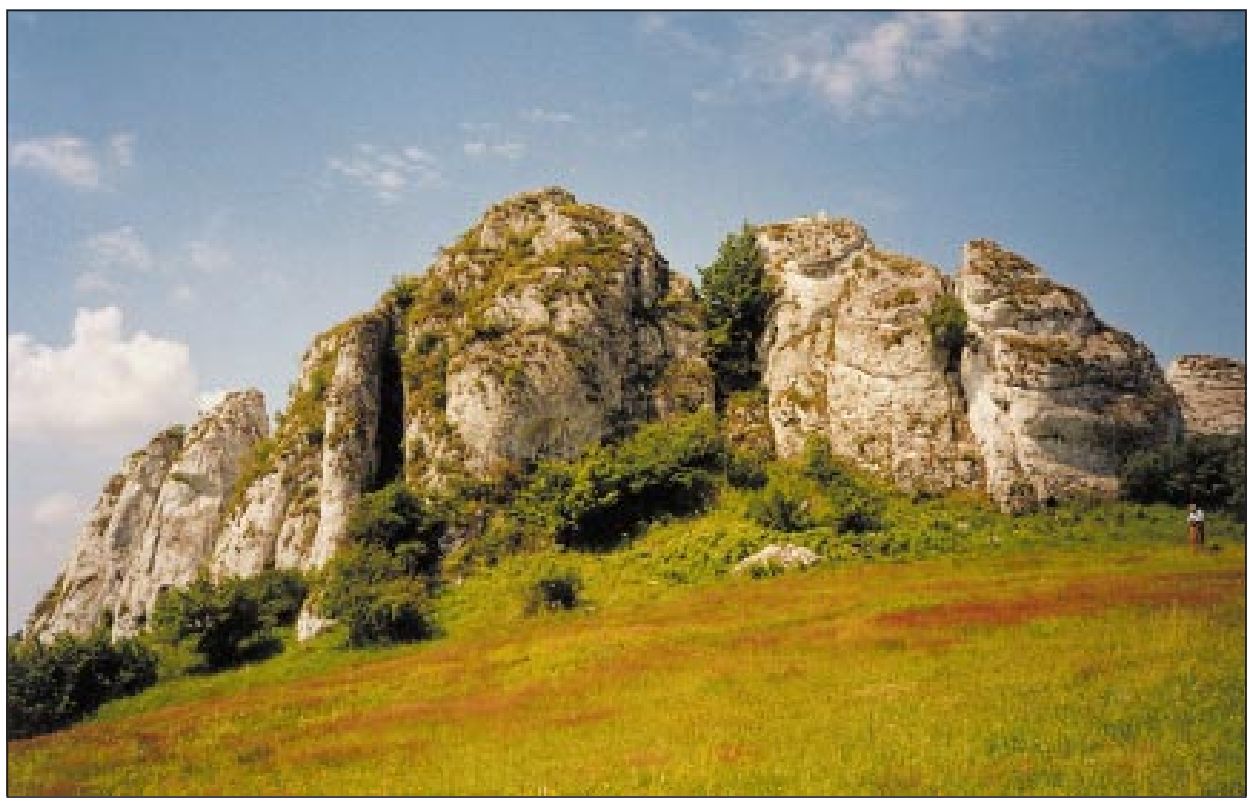

Fig. 6: Monadnock "Eysa Skata" in Jerzmanowice - eastern part of the village (Z. Alexandrowicz, 2000).

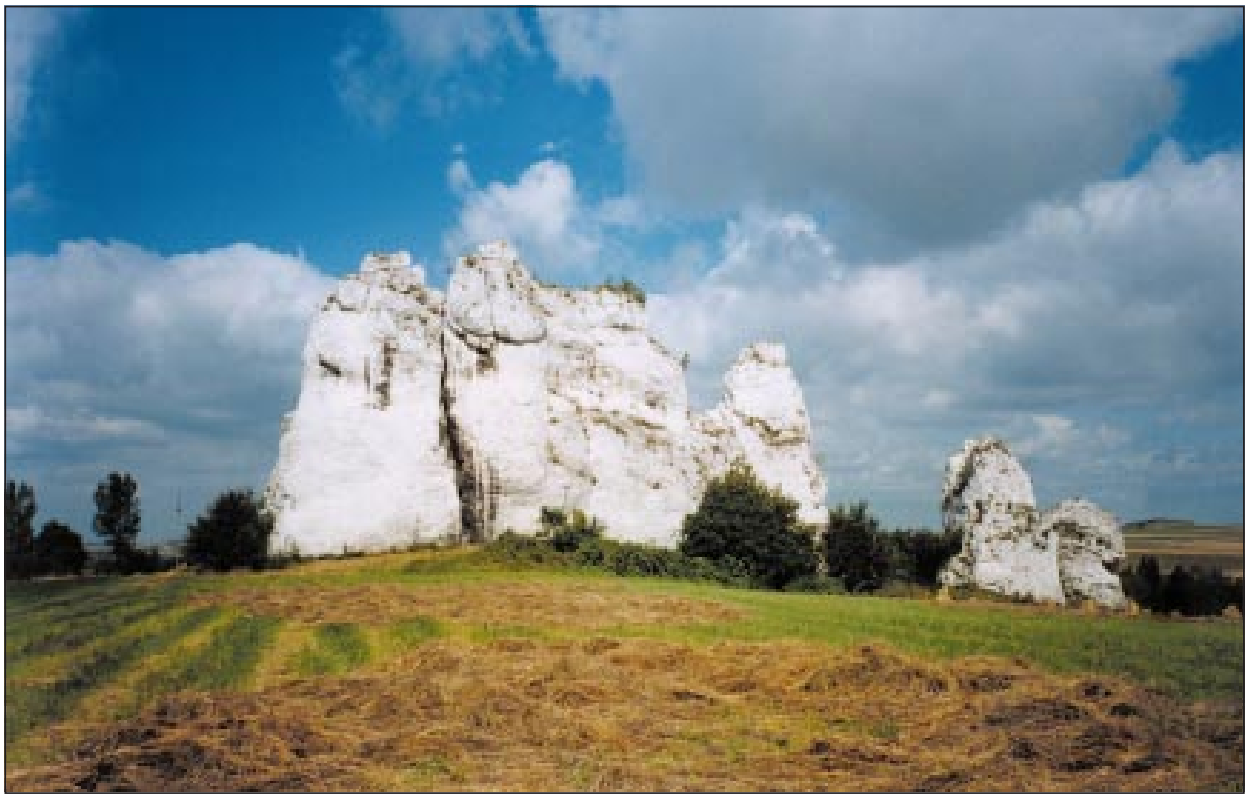

Fig. 7: Monadnock "Skała Ostatnia" in Jerzmanowice - wersten part of the village (Z. Alexandrowicz, 1998). 


\section{MALACOFAUNA}

Fossiliferous sediments of Late Quaternary age occur in many caves, rock shelters and enlarged fissures, on ledges within cliffs as well as in debris cones. Remains of vertebrates and shells of molluscs are commonly associated with traces of Palaeolithic and Neolithic colonisation (flint artefacts, charred wood, pottery). Such finds were described in detail from excavation at the foot of the monadnock Żytnia Skała in Bębło (Kowalski at al. 1967) as well as from other sites in the Ojców National Park (Chmielewski red. 1988). Late Vistulian and Holocene mollusc-bearing deposits from rock shelters and fissures also were found in many localities of the both Cracow Upland and Częstochowa Upland (S.W.Alexandrowicz 2000, W.P.Alexandrowicz 2000).

On the top surface of the Ojców Plateau the Vistulian fossiliferous sediments developed as yellow loess-like loams with limestone lumps occur rarely. A poor assemblage of molluscs with Succinea oblonga, Pupilla muscorum and Semilimax kotulai was found in the rock shelter near Przeginia (Rogożowa Skała Monadnock). It is composed of cold-tolerant open-country and mesophile snails (Tab. 1, Fig. 8 - S-1). Similar assemblages were reported from many localities of loess in the Cracow region (S.W. Alexandrowicz 1995).

The other type of assemblage occurs in grey sandy loam abounding in limestone lumps and small rock detritus. It is enriched in snails living of shady and partly shady habitats and contains few species connected mainly with Early Holocene deposits (Discus ruderatus, Vitrea crystallina, Acicula polita). The presence of xerophile elements is an interesting feature of this assemblage (Tab. 1, Fig. 8 - S-2, S-3).

Sediments and malacofauna of the Holocene climatic optimum have been noted in few localities. They enclose about $30 \%$ of woodland and bushland snails, such as: Cochlodina orthostoma, Alinda biplicata, Vitrea diaphana and Discus rotundatus, while Discus perspectivus may be indicated as the most characteristic one. Open-country and xerophile species are more or less numerous but in some localities they reach about $50 \%$ of specimens (Tab. 1, Fig. 8 - S-4, S-5).

Assemblages of the Late Holocene occur in similar sediments (grey loams with rock detritus and limestone lumps) and have been noted in rock-shelters and fissures of several monadnocks. They are composed mainly of shadow loving and mesophile snails with a high content of Clausillidae (Alinda biplicata, Cochlodina orthostoma, Clausilia dubia), with Discus rotundatus, Aegopinella minor and Isognomostoma isognomostoma. The occurrence of Cepaea vindobonensis is noteworthy. Fragments of charcoal found on the slope of the Wielka Skała Monadnock in sediments containing this fauna was dated with the ${ }^{14} \mathrm{C}$ method to $1570 \pm 100$ years BP (Gd-2523) (Tab. 1, Fig. 8 - S-6).

Table 1: List of snail species characterising the subfossil and recent fauna of molluscs on the Ojców Plateau.

Number of specimens (in logarithmic scale): I - 1-3, II - 4-9, III - 10-31, IV - 32-99, V - 100-316. Remaining explanations as in Fig. 8. (on page 49) 


\begin{tabular}{|c|c|c|c|c|c|c|c|c|c|c|c|c|}
\hline $\mathbf{E}$ & T A $X O \mathrm{O}$ & 1 & 2 & 3 & 4 & 5 & 6 & 7 & 8 & 9 & 10 & 11 \\
\hline F & Acicula polita (Hartmann) & & III & III & II & I & & & & & & \\
\hline $\mathrm{F}$ & Vertigo pusilla Müller & & II & II & IV & II & II & & III & III & & \\
\hline $\mathrm{F}$ & Orcula doliolum (Bruguiere) & & & & II & & I & III & $\mathrm{I}$ & & & \\
\hline $\mathrm{F}$ & Acanthinula aculeata (Müller) & & & & & & II & & & & & \\
\hline F & Ena montana (Draparnaud) & & II & & I & & I & & I & & & \\
\hline $\mathrm{F}$ & Discus ruderatus (Ferussac) & & & II & & & & & & & & \\
\hline $\mathrm{F}$ & Discus perspectivus (Mühlenfeld) & & & & II & & & & & & & \\
\hline $\mathrm{F}$ & Vitrea diaphana (Studer) & & & II & $\mathrm{I}$ & $\mathrm{I}$ & I & I & II & & & \\
\hline $\mathrm{F}$ & Aegopinella pura (Alder) & & II & III & III & II & & & III & & & \\
\hline $\mathrm{F}$ & Oxychilus depressus (Sterki) & & & I & I & II & I & & & I & & \\
\hline $\mathrm{F}$ & Daudebardia rufa (Draparnaud) & & & & II & & II & & & & & \\
\hline $\mathrm{F}$ & Cochlodina laminata (Montagu) & & I & I & I & I & I & I & II & & & \\
\hline $\mathrm{F}$ & Cochlodina orthostoma (Menke) & & & I & III & III & III & IV & III & I & I & I \\
\hline $\mathrm{F}$ & Ruthenica filograna (Rossmaessler) & & & I & II & I & & & & & & \\
\hline $\mathrm{F}$ & Perforatella incarnata (Müller) & & & II & I & I & & I & II & & & \\
\hline $\mathrm{F}$ & Chilostoma faustinum (Rossmaessler) & & & & I & & II & II & $\mathrm{I}$ & & & \\
\hline $\mathrm{F}$ & Isognomostoma isognomostoma (Schröter) & & & II & II & II & III & & II & & & \\
\hline B & Discus rotundatus (Müller) & & II & III & III & IV & III & II & III & III & II & \\
\hline B & Vitrea crystallina (Müller) & & III & III & & & & & & & & \\
\hline B & Aegopinella minor (Stabile) & & & & III & III & III & III & III & II & & \\
\hline B & Oxychilus glaber (Rossmaessler) & & & I & II & I & & & I & & & \\
\hline B & Alinda biplicata (Montagu) & & III & III & III & IV & IV & V & IV & II & III & III \\
\hline B & Bradybaena fruticum (Müller) & & $\mathrm{I}$ & II & II & & I & & $\mathrm{I}$ & & & \\
\hline $\mathrm{B}$ & Arianta arbustorum (Linnaeus) & I & & & & & & & & & & \\
\hline B & Helix pomatia Linnaeus & & & & & & & & & I & I & \\
\hline $\mathrm{X}$ & Cochlicopa lubricella (Porro) & & & & I & III & & & & I & & I \\
\hline $\mathrm{X}$ & Pyramidula rupestris (Draparnaud) & & IV & III & IV & IV & II & III & IV & $\mathrm{V}$ & III & \\
\hline $\mathrm{X}$ & Chondrina clienta (Westerlund) & & III & III & II & III & & III & III & IV & III & III \\
\hline $\mathrm{X}$ & Pupilla sterri (Voith) & I & & & & I & I & I & & I & II & I \\
\hline $\mathrm{X}$ & Helicella obvia (Menke) & & & & & & & & & & & IV \\
\hline $\mathrm{X}$ & Cepaea vindobonensis (Ferussac) & & & & & & II & & & I & I & \\
\hline $\mathrm{O}$ & Truncatellina cylindrica (Ferussac) & & & II & I & II & & II & III & IV & III & III \\
\hline $\mathrm{O}$ & Pupilla muscorum (Linnaeus) & II & I & II & & III & I & III & & & IV & II \\
\hline $\mathrm{O}$ & Vallonia pulchella (Müller) & & III & III & III & IV & III & IV & III & IV & IV & IV \\
\hline $\mathrm{O}$ & Vallonia costata (Müller) & & IV & IV & II & III & II & III & III & II & III & III \\
\hline $\mathrm{O}$ & Vallonia tenuilabris (Sandberger) & I & & & & & & & & & & \\
\hline $\mathrm{O}$ & Euomphalia strigella (Draparnaud) & & & & I & & I & & & & & \\
\hline M & Cochlicopa lubrica (Müller) & & & I & II & II & II & I & I & & & \\
\hline M & Vertigo alpestris Alder & & III & II & IV & II & II & & II & II & & \\
\hline M & Punctum pygmaeum (Draparnaud) & & II & III & III & III & II & & II & & & \\
\hline M & Vitrina pellucida (Müller) & & & & & & I & I & & & I & \\
\hline $\mathrm{M}$ & Semilimax kotulai (Westerlund) & I & & & & & & & & & & \\
\hline M & Vitrea contracta (Westerlund) & & II & II & III & III & III & I & $\mathrm{I}$ & III & & I \\
\hline M & Nesovitrea hammonis (Ström) & I & & II & & I & & & & & & \\
\hline M & Limacidae & I & II & II & III & II & III & I & $\mathrm{I}$ & I & I & \\
\hline M & Euconulus fulvus (Müller) & & & $\mathrm{I}$ & II & & II & & & & & \\
\hline $\mathrm{M}$ & Clausilia parvula Ferussac & & II & II & III & I & I & & III & II & & \\
\hline M & Clausilia dubia Draparnaud & II & II & III & III & II & III & III & III & III & II & \\
\hline M & Laciniaria plicata (Draparnaud) & & II & III & II & II & II & I & I & I & & \\
\hline M & Trichia hispida (Linnaeus) & I & & & & & & & & & & \\
\hline $\mathrm{M}$ & Helicigona lapicida (Linnaeus) & & & & & & III & I & II & I & II & \\
\hline $\mathrm{H}$ & Carychium tridentatum (Risso) & & $\mathrm{V}$ & IV & $\mathrm{V}$ & III & IV & II & III & III & II & \\
\hline $\mathrm{H}$ & Succinea oblonga Draparnaud & III & & & & & & & & & & \\
\hline
\end{tabular}




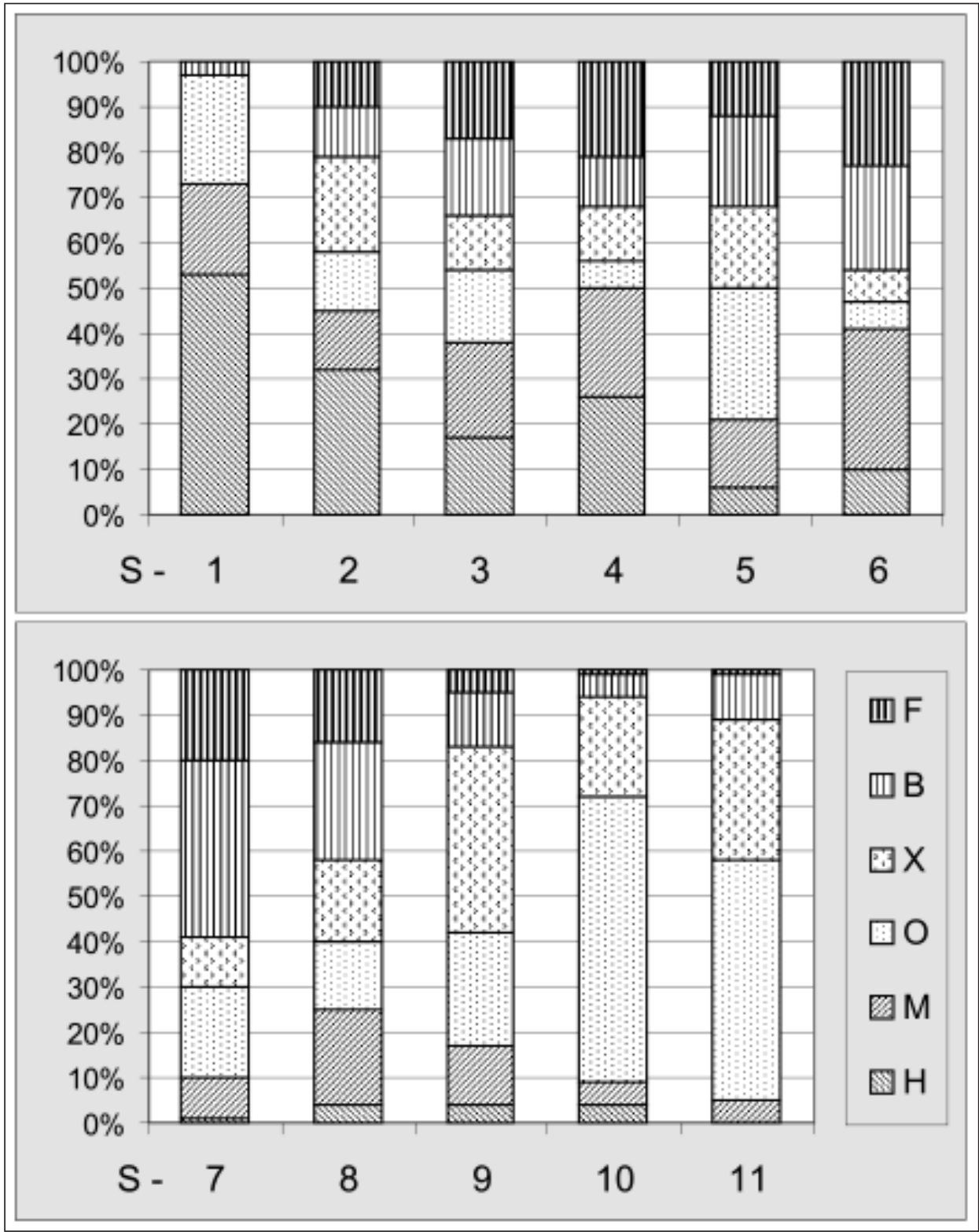

Fig. 8: Subfossil and recent assemblages of molluscs from the Ojców Plateau. Ecological groups of species: $F$ - woodland snails, $B$ - species of partly shady habitats, $X$ - xerophile snails, $O$ - open-country species, $M$ - mesophile snails, $H$ - species of humid environments. Samples quoted in the text: S-1 - Przeginia; S-2, -3, -7, -8 - Jerzmanowice, western part of the village; S-5, -6, -10, -11 - Jerzmanowice, eastern part of the village; $S-4,-8$ - monadnocks between Ractawka and Szklarka Valleys. 
The rich mollusc fauna lives recently within the monadnocks on the Ojców Plateau. It is also noted in youngest sediments and soils related to the historical period. Two main types of those assemblages are distinguished. One of them is connected with small monadnocks overgrown partly or completely with patches of light forest and bushes. It contains snails typical of shady and partly shady habitats reaching 40 - 60\%, mainly: Alinda biplicata, Cochlodina orthostoma and Orcula doliolum (Tab. 1, Fig. 8 - S-7, S-8).

Species preferring sunny environments, which cover slopes of most monadnocks, dominate in the other type of assemblage composed of xerophile and open-country snails. The first of them: Pyramidula rupestris, Chondrina clienta and Pupilla sterri inhabit mainly striped rocky surfaces. Species living within grassland occur on slopes of rocky hills and on debris-cones covered by the thin initial rendzina soil. These are Vallonia pulchella, Vallonia costata, Pupilla muscorum and Truncatellina cylindrica (Tab. 1, Fig. 8 - S-9, S-10).

In few localities the fauna typical of dry and warm sunny habitats, living on slopes around monadnocks and found in the recent rendzina soil contains numerous specimens of Helicella obvia (Tab. 1, Fig. 8 - S-11). It is a species widespread recently in South Poland, particularly in the Cracow-Częstochowa Upland, forming rich populations within deforested areas, abandoned quarries and other habitats changed by the human impact. This snail immigrated from the south during the historic period, a few hundred years ago.

\section{NATURE CONSERVATION}

The Cracow-Częstochowa Upland has a long tradition in the nature protection in Poland. Richter \& Szafer (1924) published the first well-documented project of the nature reserve in the Prądnik River Valley in Ojców. Thirty-two years later the Ojców National Park was created basing on this project. At the same time a network of nature reserves and monuments has been initiated. In the Polish Jura Chain it comprises 25 nature reserves as well as about 150 nature monuments and geological documentary sites. A new idea of landscape parks has born in this area. The Complex of six Jurassic Landscape Parks was established at 1980-1982. They cover an area of about $1200 \mathrm{~km}^{2}$ increased twofold by the buffer zone.

The concentration of protected areas and sites on the Ojców Plateau is noteworthy. Most of them are of particular geological and geomorphological values. Outcrops of different geological formations are protected in valleys cutting the plateau while on their top surface these are rocky hills, monadnocks and groups of monadnocks established as nature monuments, forming the karst relief. Caves, rock-shelters and karst springs are also under protection, here. The Landscape Park "Cracow Valleys" (Dolinki Podkrakowskie) covers a considerable part of the plateau while another Landscape Park (Dłubnia Valley) extends on their eastern margin. The Ojców National Park is the most representative and important area in the whole system of the nature conservation of the Polish Jura Chain.

The flora and fauna of the Ojców Plateau is very rich and diversified. The ploughland with patches of poor pine forests and mixed oak-lime-hornbeam forests as well as xerothermic habitats connected with calcareous bedrock spread over the top of the plateau. Different vegetation covers slopes of valleys crossing the upland. Forest of the mountain character overgrown shady slopes exposed to the north and east while termophiloeus beech-forests grown the opposite slopes. Natu- 
ral and seminatural grasslands with associations of Festucetum pallescentis develop on rocky hills, monadnocks and their surroundings.

The fauna of the Jura Chain is extraordinary rich, composed mainly of xerothermic elements, postglacial relics and Carpathian species. The most numerous are insects, spiders, molluscs, reptilians and small mammals. In respect to their natural values the Cracow Upland has been selected and indicated as a site of European importance within the framework of CORINE Biotops Programe (Dyduch-Falniowska et al. 1999) and actually proposed to the network NATURA 2000.

Several particularly interesting monadnocks, caves and geological outcrops were pointed out as sites most representatives for the geology and geomorphology of Southern Poland (Alexandrowicz \& Alexandrowicz 1999). They should be included in the European framework of GEOSITES/IUGS realised by the European Association for the Conservation of the Geological Heritage - ProGEO. A few elements of the karst relief, a.o. Jerzmanowice Monadnocks (Skałki Jerzmanowickie) are introduced on this list.

The karst landscape of the Polish Jura Chain with their rich and diversified habitats is particularly instructive for interdisciplinary investigations in manner of geo- and biodiversity applied to nature conservation (Alexandrowicz et al. 2002). This area has been also selected to create the first Polish Geopark (Alexandrowicz \& Alexandrowicz 2000).

\section{EVOLUTION OF THE RELIEF}

The polygenic relief of the Cracow Upland developed under the dominant impact of karst processes. Their evolution began during the Paleogene and continuos till now in following stages (Fig. 9).

- The development of large planation surface with hardrocks separated by selective denudation and transformed gradually from rocky hills to monadnocks.

- Miocene fault movements forming the Carpathian Foredeep, breaking the Silesian-Cracow Monocline and leading to the elevation of the Ojców Plateau.

- The Pliocene erosion and karstification, the development of a network of rocky valleys and gorges with rocky terraces, caves and cave levels, the shaping of monadnocks and microrelief of their surface.

- Intensification of physical weathering during the multiple Pleistocene glaciation, congelifraction giving masses of scree (debris cones), the successive relaxation of monadnocks along the joint and gradually enlarged fissures leading to the isolation of particular monoliths, slowly subsiding and forming small rocky labyrinths. Karstification continued in interglacial periods.

- Transformation of relief in periglacial environment during the Vistulian, particularly Late Vistulian, the deposition of loess forming a widespread cover, loess-terraces in valleys and denudation valleys (dellen) on the top surface. The fauna of cold-tolerant molluscs characterises the severe climate.

- Modification of landforms during the Holocene, controlled partly by the human impact and the development of calcareous soils (rendzina). Assemblages of molluscs indicating first the afforestation followed by the Neolithic forest clearance and finally by deforestation at Middle Ages. 


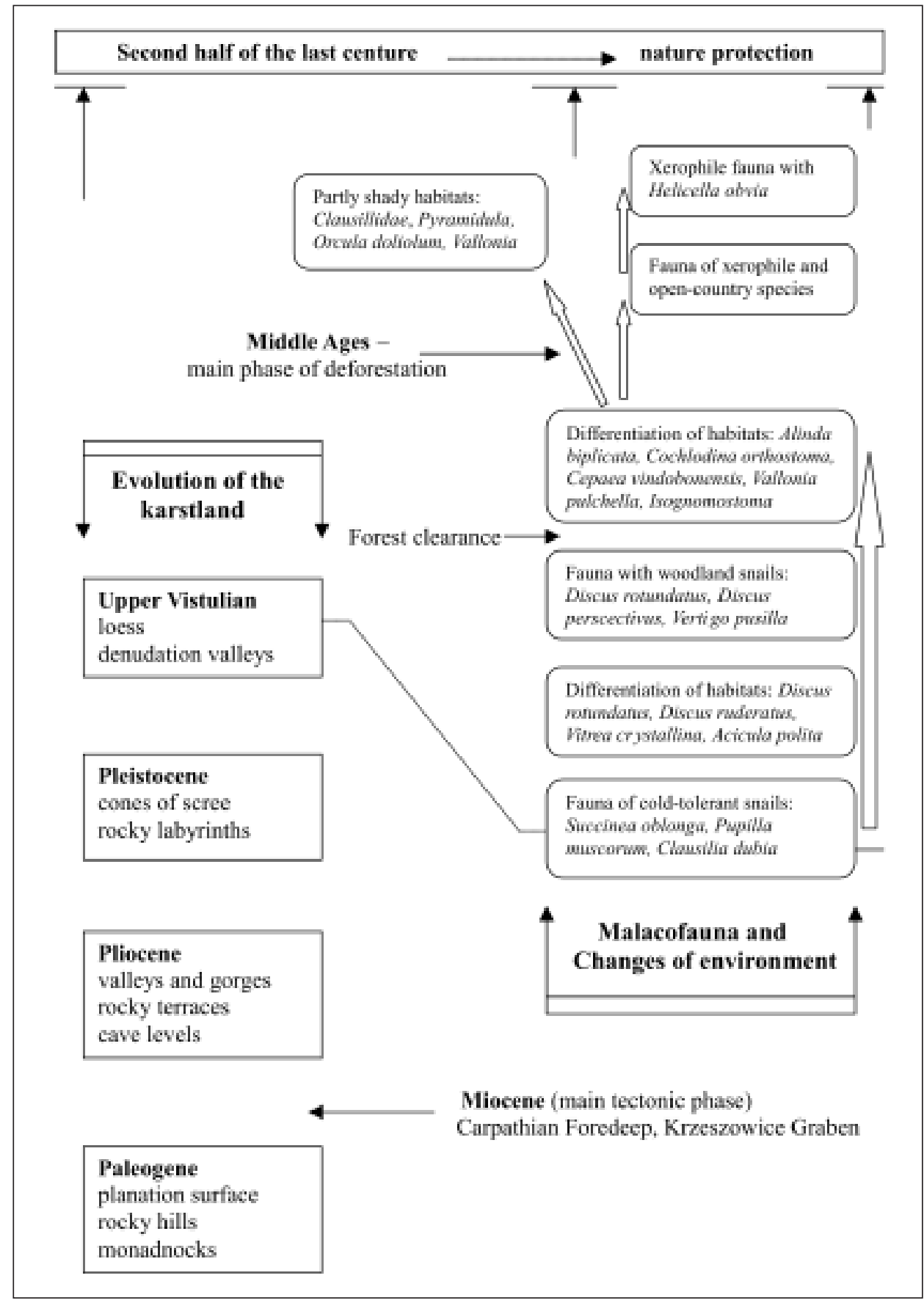

Fig. 9: Development of the karst relief and environmental changes of the Ojców Plateau. 
- Differentiation of the environment in the last few centuries connected with farming and spreading of agriculture landscape. Molluscan assemblages reflect both open and partly shady habitats as well as the immigration of xerophile species.

The Cracow Upland abounding in landforms and sediments containing fossils and artefacts is the instructive example of a Middle European karstland influenced during a long time by first natural and later anthropogenic factors. The rich network of nature/landscape parks and nature reserves/monuments as well as documentary sites preserve most valuable areas and objects. The geological history and geodiversity fit together with rich habitats and the biodiversity in a harmonious way.

\section{ACKNOWLEDGEMENTS}

The authors are grateful to Msc Krzysztof Miskiewicz for help with preparing the draws.

\section{REFERENCES}

Alexandrowicz, S.W., 1960: Budowa geologiczna okolic Tyńca. (Geological structure of the vicinity of Tyniec (Cracow Region). - Biuletyn Inst. Geol. 152 - 5-93.

Alexandrowicz, S.W., 1969: Utwory paleogenu w południowej części Wyżyny Krakowskiej. (Couches du Paléogène de la partie méridionale du Plateau de Cracovie) - Rocznik Pol. Tow. Geol. 39/4 - 681-696.

Alexandrowicz, S.W., 1995: Malacofauna of the Vistulian Loess in the Cracow Upland (S Poland). - Annales UMCS Lublin B-50 - 1-28.

Alexandrowicz, S.W., 2000: Malacofauna of Holocene cave sediments of the Cracow Upland (Poland) - Folia Quaternaria 71 - 85-112.

Alexandrowicz, S.W. \& Alexandrowicz, Z., 1999: Selected geosites of the Cracow Upland. - In: Alexandrowicz, Z. (ed.), Representative geosites of Central Europe. - Pol. Geol. Inst. Special Papers 2 - 53-60.

Alexandrowicz, W.P., 2000: Molluscan assemblages from cave and slope sediments of the Częstochowa Upland (Poland) - Folia Quaternaria 71 - 113-137.

Alexandrowicz, Z. \& Alexandrowicz, S.W., 2000: Draft project of Jurassic Geopark in the KrakówCzęstochowa Upland (Southern Poland). - Annual Meeting of ProGEO Prague, Abstracts - 6-7.

Alexandrowicz, Z., Dyduch-Falniowska, A. \& Mróz, W., 2002: Pattern of geo- and biodiversity conservation in Poland. In: Natural and cultural landscapes - the geological foundation. Conference Abstracts - 15, Royal Irish Acad. Dublin.

Barwicz-Piskorz, W., 2001: Mikrofauna górnej jury z odsłonięcia w Imbramowicach, Jura Krakowsko-Częstochowska. (Jurassic microfauna from the outcrop in Imbramowice South Poland). - Kwart. AGH, Geologia 27/2-4 - 243-255. 
Bogacz, K., 1967: Budowa geologiczna północnego obrzeżenia Rowu Krzeszowickiego. (The geological structure of the northern border of the Krzeszowice Graben) - Prace Geologiczne PAN 41 - 5-89.

Chmielewski W., Nadachowski, A., Stworzewicz, E., Bocheński, Z. \& Madeyska, T., 1988: Jaskinie Doliny Sąspowskiej. Tło przyrodnicze osadnictwa pradziejowego. - Wyd. Uniw. Warsz., pp. 173, Warszawa.

Dyduch-Falniowska, A., Każmierczakowa, R., Makomaska-Juchiewicz, M., PerzanowskaSucharska, J. \& Zająć, K., 1999: Ostoje przyrody w Polsce. (Natural sites in Poland). Instytut Ochrony Przyrody PAN, pp. 244, Kraków.

Dżułyński, S., 1952: Powstanie wapieni skalistych jury krakowskiej. (The origin of the Upper Jurassic limestones in the Cracow area). - Rocznik Pol. Tow. Geol. 21/2 - 125-180.

Dżułyński, S., Henkiel, A., Klimek, K. \& Pokorny, J., 1966: Rozwój rzeźby dolinnej południowej części Wyżyny Krakowskiej. (The Development of Valleys in the Southern Part of the Cracow Upland). - Rocznik Pol. Tow. Geol. 36/4 - 329-343.

Felisiak, I., 1992: Osady krasowe oligocenu i wczesnego miocenu oraz ich znaczenie dla poznania rozwoju tektoniki i rzeźby okolic Krakowa. (Oligocene-Early Miocene karst deposits and their importance for recognition of the development of tectonics and relief in the Carpathian Foreland, Kraków Region, Southern Poland). - Annales Soc. Geol. Pol. 62/2 - 173-207.

Gradziński, R., 1962: Rozwój podziemnych form krasowych w południowej części Wyżyny Krakowskiej. (Origin and development of subterranean Karst in the Southern part of the Cracow Upland). - Rocznik Pol. Tow. Geol. 32/4 - 429-492.

Gradziński, R., 1977: Sedymentacja piasków formierskich na skrasowiałym podłożu w środkowej części Jury Krakowsko-Wieluńskiej. (Sedimentation of „Moulding Sands” on karstified limestone surface in the Middle part of Kraków-Wieluń Upland). - Kras i Speleologia 1 (X) - 59-70.

Klimaszewski, M., 1958: Nowe poglądy na rozwój rzeźby krasowej. (Modern views on the development of the karstic relief). Przegląd Geograf. 30/3 - 421-438.

Kowalski, K., Kozłowski, J.K, Krysowska-Iwaszkiewicz, M., Pawlikowa, B. \& Wiktor, A., 1967: Badania osadów schronisk podskalnych w Żytniej Skale, Bębło, pow. Kraków. (A study of the deposits of the rock-shelters in Żytnia Skała, Bębło, Kraków District). - Folia Quaternaria 25 - 1-48.

Krysowska-Iwaszkiewicz, M., 1974: Studium mineralogiczno-petrograficzne kenozoicznych osadów lądowych Wyżyny Krakowskiej. (Mineralogical and petrographical study of Cenozoic continental deposits of the Cracow Upland). - Prace Mineralogiczne PAN 35 5-69.

Matyszkiewicz, J., 1997: Microfacies, sedimentation and some aspects of diagenesis of Upper Jurassic sediments from the elevated part of the Northern peri-Tethyan Shelf: a comparative study on the Lochen area (Schwäbische Alb) and the Cracow area (Cracow-Wielun Upland, Polen). - Berliner Geowiss. Abhandl., E, 21 - 1-111.

Pokorny, J., 1963: The Development of Mogotes in the Southern Part of the Cracow Upland. Bull.Acad. Pol. Sci., Ser. geol. et geogr., 11/3 - 169-175.

Richter, S. \& Szafer, W., 1924: Projekt rezerwatu w dolinie Prądnika. - Ochrona Przyrody 4 93-97. 
Walczak, W., 1956: Utwory czwartorzędowe i morfologia południowej części jury krakowskiej w dorzeczu Będkówki i Kobylanki. (Quaternary deposits and morphology of the southern part of the Cracow Jura in the Będkówka and Kobylańska Basin. - Biuletyn Inst. Geol., $100-419-461$.

Zaręczny, S., 1894: Mapa geologiczna okolic Krakowa i Chrzanowa. Atlas Geologiczny Galicyi z. 3 - Akademia Umiejętności, 290 pp, Kraków. 